JOSETA : Journal of Socio Economic on Tropical Agriculture

Volume 1 Nomor 2: 39 - 47 Agustus (2019)

JOSETA: Journal of Socio Economic on Tropical Agriculture http://joseta.faperta.unand.ac.id

ISSN : 2686 - 0953

\title{
Analisis Faktor-Faktor Yang Mempengaruhi Keputusan Petani Dalam Menggunakan Benih Padi Bersertifikat Di Nagari Sumani Kecamatan X Koto Singkarak Kabupaten Solok

\author{
Analysis of Factors that Influence Farmers Decisions in Using Certified Rice Seeds \\ in Nagari Sumani Kecamatan X Koto Singkarak Kabupaten Solok \\ Ade Sri Novianti ${ }^{1}$, Rahmat Syahni $Z^{2}$, Rusda Khairati ${ }^{3}$ \\ ${ }^{1}$ Mahasiswa Program Studi Agribisnis Fakultas Pertanian Universitas Andalas, Padang \\ ${ }^{2}$ Staff Pengajar Program Studi Agribisnis Fakultas Pertanian Universitas Andalas, Padang \\ ${ }^{3}$ Staff Pengajar Program Studi Agribisnis Fakultas Pertanian Universitas Andalas, Padang \\ E-mail Korespondensi: ade.srinovi@gmail.com
}

\begin{abstract}
Abstrak
Penelitian ini bertujuan untuk mendeskripsikan petani yang menggunakan benih bersertifikat dan petani yang tidak menggunakan benih bersertifikat pada usahatani padi dan mengetahui faktor yang mempengaruhi petani dalam mengambil keputusan penggunaan benih bersertifikat pada usahatani padi di Nagari Sumani Kecamatan X Koto Singkarak Kabupaten Solok. Penelitian ini dilakukan pada tanggal 26 Maret - 26 April 2019. Data yang digunakan dalam penelitian ini adalah data primer. Metode yang digunakan adalah metode survei yang menggunakan kuisioner sebagai instrumen pengumpulan data. Metode pengambilan sampel yang digunakan adalah accidental sampling. Analisis data untuk tujuan pertama dengan deskriptif kualitatif, untuk tujuan kedua dianalisis dengan deskriptif kuantitatif menggunakan aplikasi SPSS 21. Hasil analisis menunjukan bahwa petani yang menggunakan benih padi bersertifikat umumnya adalah petani yang berumur pada rentang 24-45 tahun, sebagian besar telah menempuh pendidikan hingga tingkat Sekolah Menengah Atas, memiliki penguasaan lahan sebesar 0,25Ha-1Ha, mengusahakan lahan yang berstatus milik sendiri atau tidak disewa. Dan keputusan petani dalam penggunaan benih bersertifikat dipengaruhi oleh umur petani, penerimaan usahatani, ukuran usahatani dan status kepemilikan lahan. Sedangkan jumlah tanggungan keluarga, tingkat pendidikan, dan pengalaman berusahatani tidak berpengaruh secara signifikan.
\end{abstract}

Kata Kunci: Keputusan, Benih, Bersertifikat

\begin{abstract}
This study aims to analyze (1) to describe farmers who use certified seeds and farmers who do not use certified seeds on rice farming in Nagari Sumani, Kecamatan X Koto Singkarak Kabupaten Solok. (2) find out the factors that influence farmers in making decisions on the use of certified seeds in rice farming in Nagari Sumani, Kecamatan X Koto Singkarak Kabupaten Solok. This research was conducted on March 26 - April 26 2019. The data used in this study were primary data. The method used is a survey method that uses questionnaires as an instrument for data collection. The sampling method used is accidental sampling. Data analysis for the first objective was descriptive qualitative, for the second purpose analyzed by descriptive quantitative using the SPSS application. The results of the analysis show that (1) farmers who use certified paddy seeds are generally farmers who are in the range of 24-45 years, most of whom have gone to senior high school level, seeking land that is privately owned or not rented. (2) The decision of the farmer to use certified seeds is influenced by the age of the farmer, farm income, farm size and land ownership status.
\end{abstract}

Keywords: Decision, Seed, Certified

\section{PENDAHULUAN}

Sektor pertanian merupakan salah satu sektor penting dalam pembangunan perekonomian Indonesia. Pemerintah telah menetapkan sektor pertanian sebagai prioritas utama pembangunan 
dimasa yang akan datang. Pertanian tidak hanya sebagai penyedia kebutuhan pangan bagi penduduknya, tetapi juga sebagai sumber kehidupan bagi sebagian penduduk (Nainggolan, 2005).

Pertanian mempunyai kontribusi penting terhadap perekonomian yaitu kontribusi produk dalam sumbangannya terhadap Produk Domestik Regional Bruto (PDRB) dan kontribusi pasar. Peran penting lainnya adalah dalam penyediaan kebutuhan pangan manusia apalagi dengan semakin meningkatnya jumlah penduduk yang berarti bahwa kebutuhan akan pangan juga semakin meningkat. Jika suatu negara menghendaki pembangunan yang lancar dan

berkesinambungan, maka ia harus memulainya dari daerah pedesaan pada umumnya, dan sektor pertanian pada khususnya (Uzzam, 2011).

Padi merupakan salah satu komoditas pangan nasional yang juga merupakan tanaman pokok bagi masyarakat Indonesia. Berdasarkan Survei Sosial Ekonomi Nasional oleh Badan Pusat Statistik tahun 2015, konsumsi beras perkapita Maret 2015 adalah sebesar $98 \mathrm{~kg}$ pertahun. Jumlah ini meningkat dibanding tahun sebelumnya yang hanya 97,2 $\mathrm{kg}$ pertahun. (BPS, 2015).

Dengan peningkatan tingkat konsumsi tersebut maka perlu adanya upaya dalam meningkatkan produktifitas tanaman padi. Upaya untuk meningkatkan produktifitas padi tersebut salah satunya adalah dengan penggunaan teknologi dalam meningkatkan produktifitas padi ialah penggunaan benih dari varietas unggul dengan lisensi atau sertifikat resmi (Suhendrata, 2008).

Benih merupakan salah satu input dasar dalam kegiatan produksi tanaman. Benih menjadi salah satu faktor utama yang menjadi penentu keberhasilan. Peningkatan produksi pun banyak ditunjang oleh peran benih bermutu. Menurut FAO peningkatan campuran varietas lain dan kemerosotan produksi pertanian sekitar 2,6 \% tiap generasi pertanaman adalah akibat dari penggunaan benih yang kurang terkontrol mutunya. Salah satu faktor rendahnya tingkat ketersedian benih bermutu (bersertifikat) adalah tingkat kesadaran petani untuk menggunakan benih yang berkualitas tinggi masih sangat kurang. Pada umumnya petani menyisihkan sebagian hasil panennya untuk dijadikan benih pada musim tanam berikutnya. Benih ini tentu saja tidak terjamin mutunya (Wijaya, 2017).

Menurut Soekartawi (2005) faktor-faktor yang mempengaruhi keputusan mencakup faktor sosial, faktor personal dan faktor situasional. Faktor sosial yang dimaksud adalah mencakup variabel famili atau keluarga, tetangga, klik sosial, kelompok sosial dan status social. Faktor personal atau individu adalah umur, pendidikan yang diselesaikan dan karakteristik psikologi. Sedangkan faktor situasional diantaranya adalah pendapatan usahatani, ukuran usahatani, status pemilikan tanah, prestise masyarakat dan sumber-sumber informasi yang dipergunakan.

Benih bermutu merupakan syarat untuk mendapatkan hasil panen yang maksimal. Bila pemilihan benih tidak baik, hasilnya tidak akan baik walaupun perawatan seperti pemberian pupuk dan pemberantasan hama penyakit sudah dilakukan dengan benar. Semua usaha perawatan tidak akan membuahkan hasil yang memuaskan bila yang ditanam adalah benih jelek. Untuk itulah seleksi benih harus dilakukakan dengan cermat dan sebaik-baiknya. Benih dikatakan bermutu bila jenisnya murni , bernas, kering, sehat, bebas dari penyakit, dan bebas dari campuran biji rerumputan yang tidak dikehendaki. Benih yang baik harus tinggi daya kecambahnya, paling tidak harus mencapai $90 \%$. Benih dengan kriteria tersebut biasanya mampu menghasilkan tanaman yang sehat, kekar, kokoh, dan pertumbuhan seragam (Andoko, 2002)

Kabupaten Solok merupakan sentra produksi padi di Sumatera Barat. Kabupaten Solok juga terkenal dengan sebutan kota beras di Sumatera Barat. Produksi padi di Kabupaten Solok khususnya Kecamatan X Koto Singkarak berfluktuasi dari waktu ke waktu, sementara kebutuhan pangan dari tahun ke tahun terus meningkat. Pemerintah Kabupaten Solok juga terus memotivasi semangat petani untuk meningkatkan produksi padi petani dengan memfasilitasi teknologiteknologi pertanian untuk membantu petani dalam meningkatkan produksi, diantaranya adalah penggunaan benih bersertifikat.

Benih bersertifikat merupakan salah satu unsur dari pancausahatani yang merupakan cara untuk meningkatkan produktifitas usahatani. Benih bersertifikat dapat meningkatkan jumlah 
produksi usahatani bagi petani. Benih bersertifikat adalah benih yang pada proses produksinya diterapkan cara dan persyaratan tertentu sesuai dengan ketentuan sertifikasi benih. Dapat dijelaskan pula bahwa memproduksi benih itu diawasai oleh petugas Balai Pengawasan dan Sertifikasi Benih (BPSP) yang berusaha dalam bidang pembenihan atau yang berwewenang mengadakan usaha penjualan benih benih tanaman dan ini harus memenuhi standar mutu (baik lapangan maupun laboratorium) maksudnya agar para petani atau para pemakai benih jangan dirugikan. Benih yang memenuhi standar mutu ditandai dengan label benih bersertifikat yang hanya dikeluarkan oleh BPSB (Kartasapoetra, 1992).

Adanya program benih bersetifikat tidak langsung membuat seluruh petani di Nagari Sumani Kecamatan X Koto Singkarak Kabupaten Solok beralih menggunakan benih bersertifikat. Tetapi masih banyak petani yang menggunakan benih nonsertifikat untuk input usahataninya. Hal ini disebabkan umumnya petani sulit menerima perubahan karena mengganggap usahatani yang sebelumnya sudah menguntungkan. Masih banyak petani yang membuat bibit sendiri dengan memanfaatkan hasil panen mereka yang sebelumnya. Hal ini menjadi sangat menarik bagi peneliti untuk mengetahui faktor yang mempengaruhi petani dalam memilih penggunaan benih padi pada usahataninya. Oleh karena itu peneliti ingin mengambil judul Analisis Faktor-Faktor Yang Mempengaruhi Keputusan Petani Dalam Menggunakan Benih Padi Bersertifikat Di Nagari Sumani Kecamatan X Koto Singkarak Kabupaten Solok.

Berdasarkan rumusan masalah di atas, maka timbulah pertanyaan bagaimana deskripsi petani yang menggunakan benih bersertifikat dan petani yang tidak menggunakan benih bersertifikat pada usahatani padi di Nagari Sumani Kecamatan X Koto Singkarak Kabupaten Solok?. Dan Apa faktor yang mempengaruhi petani dalam pengambilan keputusan menggunakan benih bersertifikat pada usahatani padi di Nagari Sumani Kecamatan X Koto Singkarak Kabupaten Solok?.

\section{METODE PENELITIAN}

Penelitian ini dilakukan di Nagari Sumani Kecamatan X Koto Singkarak Kabupaten Solok. Penentuan lokasi penelitian dilakukan secara sengaja (purposive). Metode yang digunakan dalam penelitian ini adalah survei. Penelitian survei adalah penelitian yang mengambil sampel dari suatu populasi dan menggunakan kuisioner sebagai alat pengumpulan data. Teknik pengambilan sampel dilakukan dengan metode accidental sampling. Accidental sampling adalah teknik pengambilan sampel yang mana peneliti mengambil sampel yang kebetulan ditemui pada saat dilakukan penelitian. Untuk tujuan pertama, yaitu mendeskripsikan petani yang menggunakan benih bersertifikat dan petani yang tidak menggunakan benih bersertifikatpada usahatani padi di Nagari Sumani Kecamatan X Koto Singkarak Kabupaten Solok, maka variabel yang diamati adalah: Umur petani, Tingkat pendidikan, jumlah tanggungan keluarga, luas lahan usahatani, status kepemilikan lahan, dan pengalaman berusahatani.

Untuk tujuan pertama, maka dilakukan analisis deskriptif kualitatif. Analisis deskriptif adalah statistik yang di gunakan untuk menganalisa data dengan cara mengambarkan atau mendeskripsikan data yang telah terkumpul sebagaimana adanya tanpa ada maksud membuat kesimpulan yang berlaku untuk umum atau generalisasi (Sugiono, 2007). Untuk mendeskripsikan petani yang menggunakan benih bersertifikat dan petani yang tidak menggunakan benih bersertifikat dilakukan dengan wawancara langsung kepada petani . Pertanyaan yang di ajukan saat wawancara merupakan pertanyaan yang sudah di siapkan pada kuisoner.

Untuk tujuan kedua, yaitu mengetahui faktor yang mempengaruhi petani dalam pengambilan keputusan penggunaan benih bersertifikat pada usahatani padi di Nagari Sumani Kecamatan X Koto Singkarak Kabupaten Solok variabel yang diamati yaitu umur, 
tanggungan keluarga, pendidikan, pengalaman, penerimaan usahatani, ukuran usahatani, dan status kepemilikan lahan petani.

Untuk tujuan kedua, digunakan analisis deskriptif kuntitatif dengan teknik analisis regresi logistik. Analisis regresi logistik digunakan untuk mengukur hubungan antara satu variabel dependen (Y) yang bersifat dikotomus (memiliki dua kemungkinan nilai) dengan variabel variabel indenpendent $(\mathrm{X})$ dari jenis kuantitatif atau kualitatif. Bentuk persamaan umum regresi logistik sebagai berikut:

$\mathrm{Y}=\operatorname{Ln}\left(\frac{P i}{1-p}\right)=\beta 0+\beta_{1} \mathrm{X}_{1}+\beta_{2} \mathrm{X}_{2}+\beta_{3} \mathrm{X}_{3}+\beta_{4} \mathrm{X}_{4}+\beta_{5} \mathrm{X}_{5}+\beta_{6} \mathrm{X}_{6}+\beta_{7} \mathrm{X}_{7}$

Keterangan:

$\mathrm{Y}=$ Logaritma natural rasio keputusan petani menggunakan benih

bersertifikat $\beta 0=$ Konstanta

$\beta 1, \beta 2, \beta 3, \beta 4, \beta 5, \beta 6, \beta 7=$ Koefisien regresi masing-masing variabel

$\mathrm{X}_{1}, \mathrm{X}_{2}, \mathrm{X}_{3}, \mathrm{X}_{4}, \mathrm{X}_{5}, \mathrm{X}_{6}, \mathrm{X}_{7}=$ variabel bebas dalam penelitian

\section{Uji overall}

Uji ini digunakan untuk mengetahui apakah secara bersama sama terdapat pengaruh yang nyata dari variabel indenpendent terhadap variabel dependent

\section{Menilai kelayakan model regresi}

Kelayakan model regresi di nilai dengan menggunakan uji hosmer dan lemeshow goodnes of fit test. Model ini digunakan untuk mengetahui apakah model yang di bentuk sudah mampu memprediksi dengan baik atau tidak.

i. Jika nilai statistik Hosmer and Lemeshow goodness of fit Test sama dengan atau kurang dari $\alpha(0,05)$ maka hipotesis nol ditolak. Hal ini berarti ada perbedaan signifikan antara model dengan nilai observasinya sehingga goodness of fit model tidak baik digunakan karena model tidak dapat memprediksi nilai observasinya.

ii. Jika nilai statistik Hosmer and lemeshow goodness of fit test lebih besar dari $\alpha(0,05)$ maka hipotesis nol tidak dapat ditolak dan berarti model mampu memprediksi nilai observasinya atau model diterima karena sesuai dengan observasinya.

\section{Kofisien determinasi}

Koefisien determinasi $\left(\mathrm{R}^{2}\right)$ merupakan pengujian untuk mengukur berapa jauh kemampuan variabel independent dalam menerangkan variabel dependent. Niali $R^{2}$ berkisar antara 0 sampai 1. Bila nilai $\mathrm{R}^{2}$ kecil berarti kemampuan variabel independen dalam menjelaskan variabel dependen sangat terbatas. Sedangkan jika $\mathrm{R}^{2}$ mendekati 1 berarti variabel independen dapat memberikan hampir semua informasi yang diperlukan untuk memprediksi variabel dependen.

\section{Uji partial}

Setelah dilakukann analisis kelayakan model regresi logistik kemudian dilakukan pengujian parsial yang dilakukan untuk menguji apakah terdapat pengaruh yang signifikan dari ketujuh variabel independen yang digunakan.

\section{HASIL DAN PEMBAHASAN}

\section{A. Gambaran umum daerah penelitian}

Kenagarian Sumani merupakan salah satu kenagarian yang berada di wilayah pemerintahan Kecamatan X Koto Singkarak. Kenagarian Sumani ini memiliki luas wilayah $1.560 \mathrm{Ha}$. Secara geografis Nagari Sumani terletak pada $00^{0} 19^{\prime} 40^{\prime \prime}$ LS $-00^{0} 16^{\prime} 15^{\prime \prime}$ LS dan $100^{0} 41^{\prime} 20$ BT- $100^{\circ}$ $41^{\prime} 50^{\prime}$ 'BT dengan suhu rata-rata $30^{\circ} \mathrm{C}$ dan tinggi dari permukaan laut adalah 400 mdl. Secara administrasi, Kenagarian Sumani memiliki daerah batasan yakni sebelah utara berbatasan dengan Kenagarian Singkarak, sebelah barat laut berbatasan dengan Kenagarian Saning Bakar, sebelah selatan berbatasan dengan Kenagarian Tanjung Bingkung, sebelah timur berbatasan dengan Kenagarian Aripan, serta sebelah barat berbatasan dengan Kenagarian Koto Sani. Berdasarkan administrasi pemerintahannya, Nagari Sumani memiliki 12 jorong. 
Keadaan iklim Nagari Sumani beriklim tropis. Ditinjau dari segi hidrologinya secara umum dibedakan atas dua yaitu air pegunungan dan air tanah. Secara umum tanah di Nagari Sumani berjenis andosol. Penggunaan lahan terbesar digunakan untuk hutan rakyat dan sawah. Untuk status kepemilikan tanah dinagari sumanii pada umumnya merupakan tanah ulayat (tanah mili kaum) yang mana pengguaan tanah harus dimusyawarahkan pada pemangku adat setempat.

Untuk aspek kependudukan di nagari Sumani memiliki jumlah total penduduk sebanyak 5.442 jiwa yaitu dari $1.375 \mathrm{KK}$. Dengan kepadatan penduduk yaitu $348 \mathrm{jiwa} / \mathrm{km}^{2}$. Mata pencaharian penduduk di Nagari Sumani beragam seperti PNS, Petani, nelayan, dan pegawai swasta. Seluruh jorong di nagari Sumani memiliki potensi untuk diusahakan tanaman padi. Sementara saran dan prasana yang ada di Nagari Sumani terbilang cukup dan memadai.

\section{B. Karakteristik petani yang menggunakan benih bersertifikat dan petani yang tidak menggunakan benih bersertifikat}

Berdasarkan data yang telah diperoleh, maka dapat di kemukakan krakteristik petani meliputi umur, tingkat pendidikan, jumlah tanggungan keluarga, luas lahan usahatani, status kepemilikan lahan, dan pengalaman berusaha tani. Maka dapat di lihat pada Tabel 1 Tabel 1. Karakteristik petani

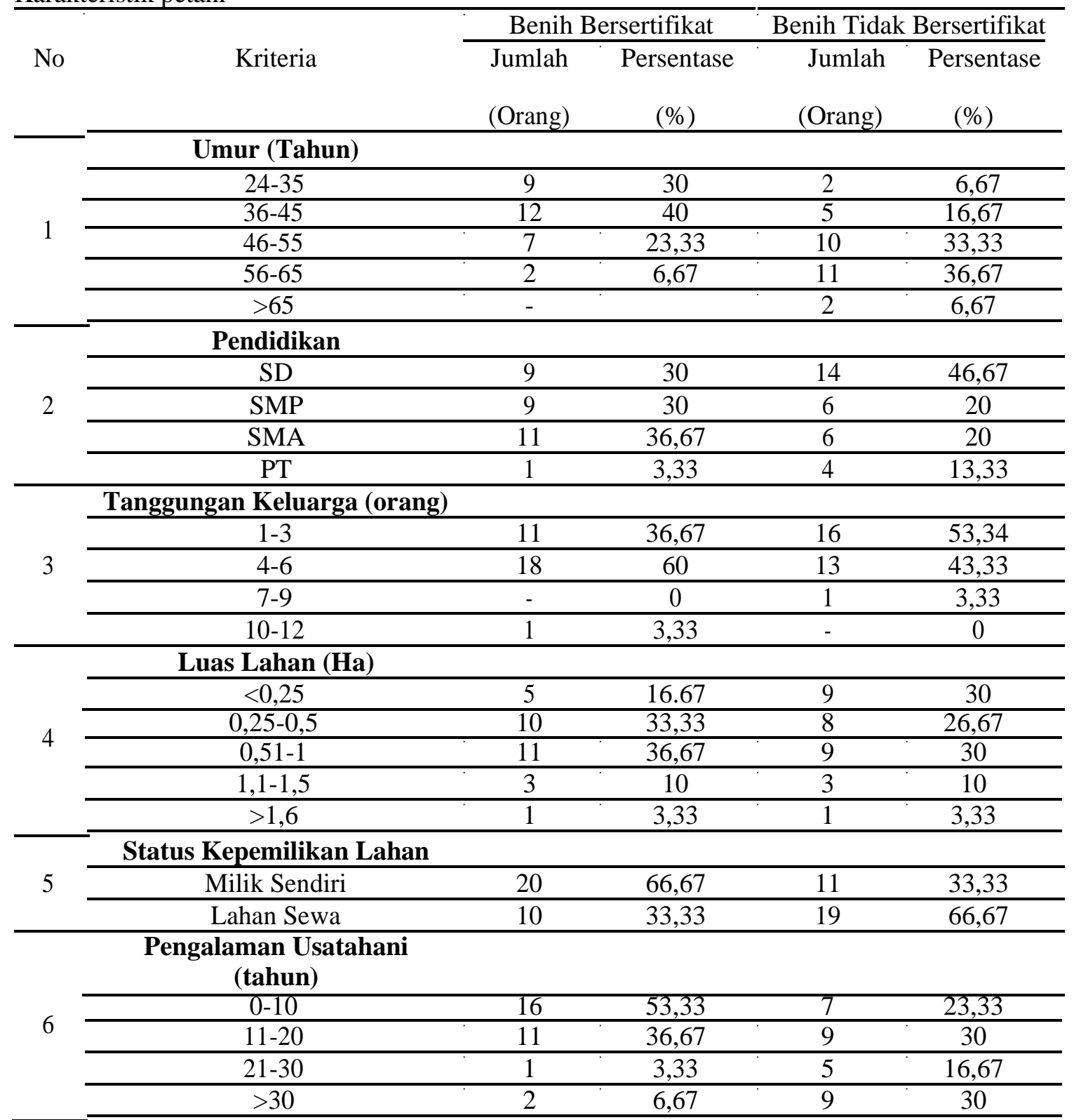


Dari Tabel 1 dapat dilihat bahwa petani yang menggunakan benih bersetifikat rata-rata kelompok umur yang paling banyak adalah 36-45 tahun yaitu sebanyak 12 orang atau sebesar $40 \%$. Sedangkan pada responden petani pengguna benih padi tidak bersertifikat yang paling banyak adalah kelompok 56-65 tahun yaitu sebanyak 11 orang atau sebesar 36,67\%. Secara keseluruhan dari 60 orang sampel petani yang diteliti, 58 orang petani berusia produktif dan 2 orang petani berusia tidak produktif. Dari tabel juga dapat diketahui petani muda usia 24-45 tahun lebih cendrung menggunakan benih bersertifikat.

Pendidikan yang ditempuh oleh petani pengguna pengguna benih padi bersertifikat dan petani pengguna benih padi tidak bersertifikat adalah pendidikan formal. Tingkat pendidikan formal yang ditempuh oleh petani padi di Nagari Sumani adalah mulai dari SD sampai dengan Perguruan Tinggi. Pendidikan terakhir petani pengguna benih padi bersertifikat yang paling banyak adalah SMA yaitu 11 orang atau sekitar 36,67\% sedangkan petani pengguna benih padi tidak bersertifikat paling banyak pendidikan terakhir ditingkat SD yaitu 14 orang atau sekitar $46,67 \%$. Dari hasil ini dapat dilihat bahwa umumnya petani yang menggunakan benih bersertifikat lebih memiliki pendidikan yang cukup matang atau menempuh jenjang pendidikan SMP dan seterusnya.

Pengguna benih padi bersertifikat paling banyak yang memiliki tanggungan keluarga sebanyak 4-6 orang yaitu 18 petani atau sebesar $60 \%$. Sedangkan untuk petani pengguna benih padi tidak bersertifikat paling banyak pada kelompok yang memiliki tanggungan keluarga sebanyak 1-3 orang yaitu 16 petani atau sebesar 53,34\%. Dari hasil ini dapat diketahui petani yang menggunakan benih bersertifikat memiliki anggota keluarga yang lebih banyak dibandingkan petani yang tidak menggunakan benih bersertifikat.

Masyarakat petani Nagari Sumani umumnya mengusahakan lahan pertanian berupa lahan sewa dan lahan milik sendiri. Ada beberapa dari petani sampel yang memiliki lahan sawah yang terpisah letak piringan sawahnya namun masih dalam satu hamparan yang sama. Petani pengguna benih padi bersertifikat paling banyak memiliki luas lahan sebesar kisaran 0,25 $\mathrm{Ha}-1$ Ha yaitu sebanyak 21 orang atau sebesar $70 \%$. Sedangkan petani yang menggunakan benih padi tidak bersertifikat tersebar cukup merata pada pemilikan luas lahan sebesar kisaran $0 \mathrm{Ha}-1 \mathrm{Ha}$ yaitu sebanyak 8 sampai 9 orang petani.

Status penguasaan lahan petani pengguna benih padi bersertifikat dengan petani pengguna benih padi tidak bersertifikat terdiri dari dua jenis kepemilikan lahan yaitu lahan sewa dan lahan milik pribadi. Petani yang mengusahakan lahan sewa haruslah membagi hasil produksi padinya kepada pemilik lahan. Status kepemilikan lahan dari 60 petani yang di jadikan sampel 51,67\% petani mengusahakan lahan milik sendiri dan $48,33 \%$ mengusahakan lahan sewa yang tersebar pada petani pengguna benih padi bersertifikat dan benih padi tidak bersertifikat. Sebanyak 20 orang petani menggunakan benih bersertifikat mengusahakan lahan milik sendiri. Sedangkan petani yang tidak menggunakan benih bersertifikat umumnya mengusahakan lahan yang disewa kepada oranglain.

Umumnya petani yang menggunakan benih bersertifikat memiliki pengalaman berusahatani yang lebih muda atau baru dibandingkan petani yang tidak menggunakan benih bersertifikat. Dari Tabel 1 dapat dilihat bahwa petani pengguna benih padi bersertifikat paling banyak memiliki pengalaman berusahatani 0-10 tahun yaitu sebanyak 16 orang atau sebesar 53,33\%. Sedangkan petani yang tidak menggunakan benih bersertifikat paling banyak memiliki pengalaman berusahatani diatas 20 tahun atau sebesar $46,67 \%$.

\section{Faktor Yang Mempengaruhi Keputusan Petani dalam Menggunakan Benih Padi Bersertifikat}

Faktor yang diduga dapat mempengaruhi keputusan petani dalam memilih penggunaan benih padi bersertifikat yaitu umur, jumlah tanggungan keluarga, pendidikan, pengalaman berusahatani, penerimaan usahatani, ukuran usahatani,dan status kepemilikan lahan. Dalam analisis menggunakan metode analisis regresi logistik dengan menggunakan sebanyak 60 sampel petani dengan bantuan aplikasi SPSS 21. Hasil dugaan model regresi logistik 
menunjukan pada tingkat kepercayaan $95 \%(\alpha=0,05)$. Berikut beberapa pengujian yang dilakukan dalam analisis regresi logistik:

a. Uji overall/ Uji Omnibus

Uji omnibus dapat diartikan sebagai uji serempak (overall) yang dilakukan untuk mengetahui apakah secara bersama-sama terdapat pengaruh yang nyata dari variabel independen terhadap variabel dependen. Nilai chi-square hitung yang didapatkan adalah $34,025>$ chi-square tabel 14,067 dan nilai signifikansinya $0,000<0,05$ maka dapat disimpulkan bahwa model dengan mengikutsertakan variabel bebas dikatakan lebih baik dan dapat dikatakan bahwa terdapat pengaruh nyata secara simultan atau bersama-sama. Dari uji ini dapat dikatakan bahwa minimal ada satu variabel $X$ yang signifikan mempengaruhi variabel Y.

b. Uji Hosmer dan Lemeshow

Uji Hosmer and Lemeshow digunakan untuk menentukan apakah model yang dibentuk sudah mampu memprediksi dengan baik atau tidak. Hasil dari pengujian model prediksi dengan observasi nilai chi-square hitung yang didapat adalah $11,352<$ chi-square tabel 15,507 Dengan nilai signifikansi $(0,183)>$ alpha $(0,05)$ maka dapat disimpulkan bahwa model yang digunakan memiliki probabilitas prediksi yang sama dengan probabilitas yang diamati. Dapat disimpulkan bahwa model yang terbentuk cukup mampu menjelaskan data dan model regresi logistik biner yang digunakan tersebut fit

c. Model Summary (Hasil Cox \& Snell R Square dan Nagelkerke R Square)

Hasil dari pengujian yang dilakukan menghasilkan nilai Nagelkerke R Square. Nagelkerke $R$ Square memiliki interpretasi yang mirip dengan koefisien determinasi pada regresi linear. Hasil Nagelkerke R Square sebesar 0,577 yang artinya variabel independen (X) dapat mempengaruhi variabel dependen $(\mathrm{Y})$ sebesar $58 \%$. Artinya seluruh variabel independen dapat mempengaruhi variabel dependen secara serentak pada kisaran 58\%. Sedangkan $42 \%$ lainnya dipengaruhi oleh variabel lain yang tidak dimasukkan kedalam penelitian.

d. Uji Partial

Setelah dilakukan analisis kelayakan model regresi logistik kemudian dilakukan pengujian parsial yang dilakukan untuk menguji apakah terdapat pengaruh yang signifikan dari ketujuh variabel independen yang digunakan. Penelitian ini menggunakan tingkat signifikansi 5\%, sehingga suatu variabel independen dianggap memiliki pengaruh yang signifikan apabila nilai tingkat signifikansinya lebih kecil daripada 0,05 . Berikut ini adalah signifikansi untuk masing-masing variabel independen baserta koefisien regresi:

Tabel 2. Hasil Pengujian Variabel

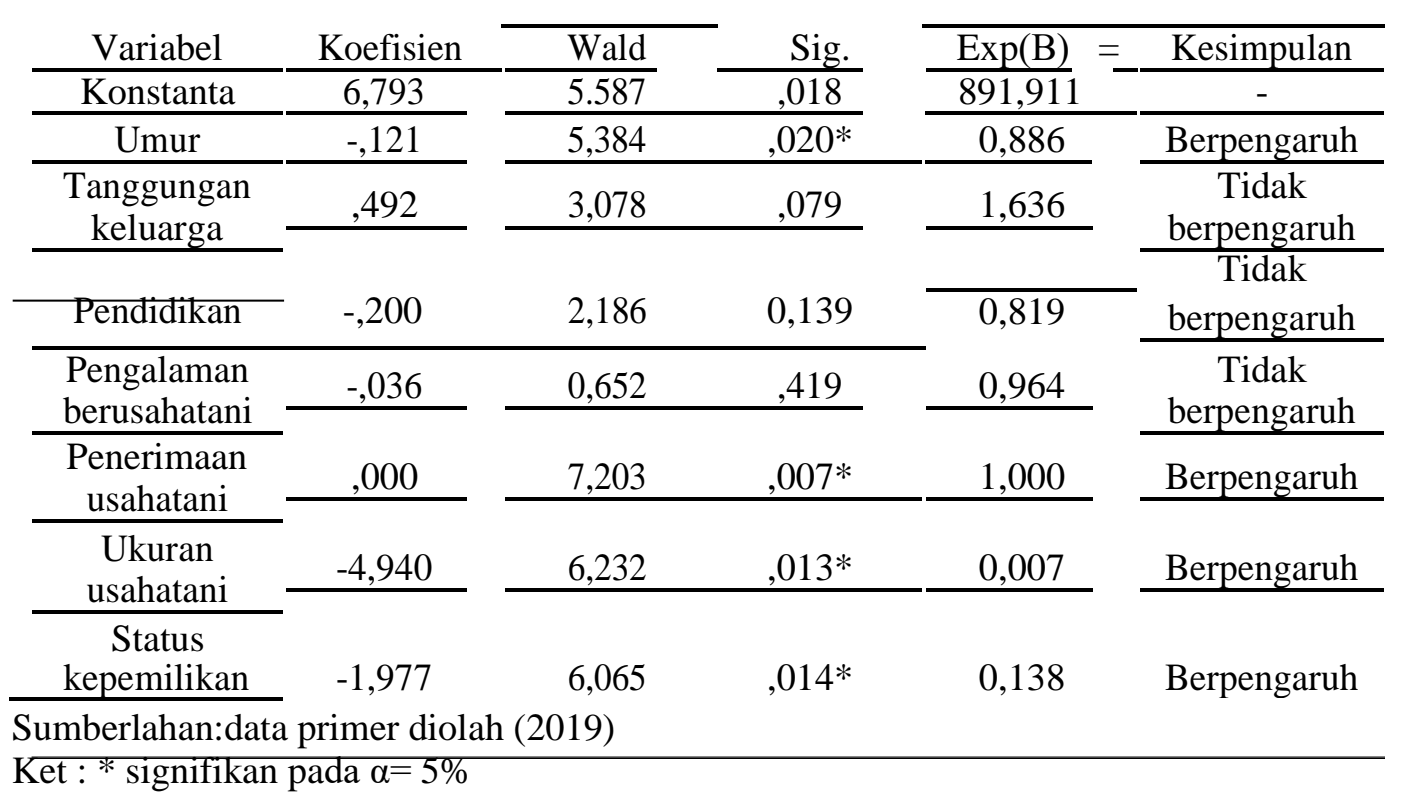


Melalui Tabel 2 dapat diperoleh suatu persamaan model regresi logistik sebagai berikut:

$\mathrm{Y}=\ln \left(\begin{array}{c}p i \\ 1-p i\end{array}\right)=6,793-0,1211 \mathrm{X} 1+0,005 \mathrm{X} 5-4,940 \mathrm{X} 6-1,9777 \mathrm{X} 7$

Variabel umur memiliki tingkat signifikansi sebesar 0,020 atau lebih kecil dari $\alpha(0,05)$, yang artinya terdapat pengaruh nyata yang signifikan terhadap keputusaan petani memilih penggunaan benih padi bersertifikat. Dengan nilai koefisien bernilai minus maka hal ini menunjukan semakin rendahnya umur petani, kemungkinan petani memilih menggunakan benih padi bersertifikat semakin meningkat. Nilai odds ratio pada variabel umur petani adalah sebesar 0,886 , yang artinya setiap terjadi satu tahun pengurangan umur petani maka peluang petani memilih benih bersertifikat bertambah 0,886 kali.

Variabel jumlah tanggungan keluarga memiliki nilai koefisien positif sebesar 0,492 . Hal ini menunjukan bahwa semakin banyak jumlah tanggungan maka petani akan semakin cendrung memilih untuk menggunakan benih padi bersertifikat. Jumlah tanggungan memiliki tingkat signifikansi sebesar 0,153 , nilai ini lebih besar dari pada $\alpha(0,05)$ yang artinya tidak terdapat pengaruh yang signifikan antara jumlah tanggungan keluarga dengan pengambilan keputusan petani untuk memilih menggunakan benih padi bersertifikat.

Variabel pendidikan memiliki nilai koefisien yang negatif, hal ini menunjukan bahwa semakin rendah petani menempuh pendidikan maka petani cendrung menerima inovasi teknologi dan memilih menggunakan benih padi bersertifikat. Tingkat signifikansi dari variabel pendidikan adalah sebesar 0,139 atau lebih besar dari nilai $\alpha(0,05)$, yang artinya tidak terdapat pengaruh yang signifikan antara pendidikan petani dengan keputusan petani untuk menggunakan benih padi bersertifikat.

Variabel pengalaman berusahatani memiliki nilai koefisien negatif. Hal ini menunjukan bahwa semakin lama pengalaman petani berusahatani maka petani akan cendrung tidak menggunakan benih padi bersertifikat. Pengalaman berusahatani memiliki nilai signifikasi sebesar 0,419 atau lebih besar dari $\alpha(0,05)$ yang artinya tidak terdapat pengaruh yang signifikan antara pengalaman berusahatani dengan keputusan untuk menggunakan benih padi bersertifikat.

Variabel penerimaan usahatani memiliki nilai koefisien yang positif. Hal ini menunjukan bahwa semakin besar penerimaan petani maka petani akan cendrung memilih untuk menggunakan benih padi bersertifikat. Penerimaan memiliki nilai signifikansi sebesar 0,007 atau lebih kecil daripada $\alpha(0,05)$ yang artinya bahwa terdapat pengaruh yang signifikan antara penerimaan petani terhadap keputusan petani untuk menggunakan benih padi bersertifikat. Petani pengguna benih bersertifikat menerima penerimaan rata-rata sebesar $\mathrm{Rp}$ 11.197.620 dalam satu kali panen yang produksi dijual dalam bentuk gabah. Sedangkan petani yang menggunakan benih padi tidak bersertifikat memiliki penerimaan rata-rata sebesar Rp 9.417.420 dalam satu kali panen. Sehingga dapat dikatakan penerimaan petani pengguna benih padi bersertifikat lebih tinggi dari petani yang tidak menggunakan benih bersertifikat.

Variabel Ukuran usahatani memiliki nilai koefisien yang negatif. Hal ini menunjukan bahwa semakin luas lahan yang dimiliki petani maka petani akan cendrung tidak memilih menggunakan benih padi bersertifikat. Ukuran usahatni memiliki nilai signifikasi sebesar 0,013 atau lebih kecil daripada $\alpha(0,05)$ yang artinya bahwa terdapat pengaruh yang signifikan antar ukuran usahatani terhadap keputusan petani untuk menggunakan benih padi bersertifikat.

Status kepemilikan lahan merupakan dummy variabel yang signifikan terhadap pemilihan benih. Variabel status kepemilikan lahan memiliki nilai koefisien yang negatif. Hal ini menunjukan bahwa petani yang menggarap lahan atau mengusahakan lahan sewa cendrung tidak akan memilih untuk menggunakan benih padi yang bersertifikat. Status kepemilikan lahan memiliki nilai signifikasi sebesar 0,014 atau lebih kecil daripada $\alpha(0,05)$ yang artinya bahwa terdapat pengaruh yang signifikan antara status kepemilikan lahan terhadap keputusan petani untuk menggunakan benih padi bersertifikat. 


\section{A. Kesimpulan}

\section{KESIMPULAN}

Karakteristik petani yang menggunakan benih padi bersertifikat umumnya adalah petani yang memiliki umur pada rentang 24-45 tahun (70\%), sebagian besar menempuh pendidikan hingga tingkat Sekolah Menengah Atas atau sederajat (36,67\%), jumlah tanggungan keluarga kisaran 4-6 orang (60\%), memiliki penguasaan lahan sebesar 0,25 Ha-1 Ha (67\%), memiliki pengalaman usahatani 0-10 tahun (53,33\%), dan dalam hal status kepemilikan lahan umumnya petani yang mengusahakan lahan sendiri memilih menggunakan benih bersertifikat $(66,67 \%)$. Sedangkan karakteristik petani yang tidak menggunakan benih bersertifikat umumnya adalah petani yang berusia 46-65 tahun (70\%), menempuh pendidikan formal hingga tingkat Sekolah Dasar (46,67\%), memiliki jumlah tanggungan keluarga 1-3 orang $(53,34 \%)$, memiliki penguasaan lahan sebesar 0-0,5 $\mathrm{Ha}(56,67 \%)$, memiliki pengalaman berusahatani 11-20 tahun $(30 \%)$, serta status kepemilikan lahan kebanyakan petani adalah lahan sewa $(66,67 \%)$.

Dari tujuh variabel yang dianalisis terdapat empat variabel yang memiliki pengaruh signifikan terhadap pengambilan keputusan petani yaitu umur petani, penerimaan usahatani, ukuran luas lahan usahatani dan status kepemilikan lahan oleh petani. Sedangkan tiga faktor lainnya yaitu jumlah tanggungan keluarga, pendidikan dan pengalaman usahatanitidak berpengaruh secara signifikan

\section{B. Saran}

Bagi Pemerintah Nagari Sumani setelah diketahui faktor yang mempengaruhi keputusan petani ini hendaknya bisa tepat sasaran dalam melakukan penyuluhan pertaniannya. Sasaran penyuluhan secara intensif kepada petani yang berusia 50 tahun keatas, yang menempuh pendidikan hingga tingkat Sekolah Menengah Pertama kebawah, yang memiliki jumlah tanggungan sedikit, luas lahan yang kecil, dan yang mengusahakan lahan berstatus sewa. Untuk petani yang belum mau mengambil keputusan untuk menerima adopsi ini maka penyuluh bisa lebih giat menekankan manfaat dan kegunaan benih bersertifikat kepada petani. Dan Sebaiknya petani menggunakan benih padi bersertifikat sehingga dapat meningkatkan penerimaan yang akan diperoleh petani.

\section{DAFTAR PUSTAKA}

Andoko, Agus. 2002. Budidaya Padi secara Organik. Penebar Swadaya: Jakarta.

Badan Pusat Statistik Indonesia. 2016. Statistical Year Book Of Indonesia 2016. BPS Indonesia Kartasapoetra, Ance. 1992. Teknologi Benih. PT Asdi Mahasatya: Jakarta.

Nainggolan, Kasman. 2005. Pertanian Indonesia Kini dan Esok. Pustaka Sinar Harapan: Jakarta.

Soekartawi. 2005. Prinsip Dasar Komunikasi Pertanian. UI Press: Jakarta.

Suhendrata, Tota. 2008. Peran Inovasi Teknologi Pertanian Dalam Peningkatan Produktivitas Padi Sawah Untuk Mendukung Ketahanan Pangan. Prosiding Seminar Nasional Teknik Pertanian. Yogyakarta. 18-19 November 2008.

Sugiyono. 2016. Metode Penelitian Kuantitatif, Kualitatif, Dan R\&D. PT Alfabet:Bandung Uzzam, Fathihah Ulfah. 2011. Analisis Faktor Faktor yang Mempengaruhi Produksi Padi Di Kabupaten Solok. Universitas Andalas Fakultas Ekonomi: Padang

Wijaya, Irawan Yudha. 2017. Analisis Faktor- Faktor Yang Mempengaruhi Petani Dalam Memilih Benih Bersertifikat Pada Usahatani Padi Di Kabupaten Bantul. Program Studi Agribisnis: Universitas Muhammadyah Yogyakarta 
